\title{
De handen (af?) van de verzorgingsstaat
}

In de Volkskrant van 31 maart 2012 verscheen het artikel 'Amerika exporteert zijn oplossing voor sociale problemen'. Hierin staat een interview met de Franse socioloog Loïc Wacquant, opgetekend door Pieter Hilhorst. Aanleiding was het verschijnen van de Nederlandse vertaling van het boek Urban outcasts: A comparative sociology of advanced marginality. Wacquant betoogt dat de Europese sociale zekerheidsstelsels zich, zoals dat in de Verenigde Staten al eerder gebeurde, steeds meer laten kenmerken door de 'neoliberale staatsopvatting'. In de Verenigde Staten 'is de afgelopen twintig jaar een beleid gevoerd van liberalisering en deregulering. Daarvan hebben vooral bedrijven en rijken geprofiteerd. [...] Ondertussen trad de staat aan de andere kant van het sociale spectrum steeds strenger op. Zero tolerance deed zijn intrede waarbij ook kleine misdaden streng werden bestraft. Sociale uitkeringen werden in de tijd beperkt en werklozen werden verplicht om te werken'. Wacquant betoogt in Urban outcasts dat dit beleid mede heeft bijgedragen aan de verheviging van diepgewortelde sociale problematiek in achterstandsbuurten in de grote steden van de Verenigde Staten.

Ter verdere verduidelijking gebruikt Wacquant een metafoor, ontleend aan Pierre Bourdieu: het onderscheid tussen de linker- en rechterhand van de staat. 'De linkerhand is de verzorgende hand. Het is de hand die burgers op weg helpt. [...] De rechterhand is meer een vuist. Die corrigeert burgers als ze de fout in gaan.' Ook in Europese welvaartsstaten die geroemd worden om hun sociale zekerheidsstelsels, zou het verzorgende karakter van de staat steeds meer plaatsmaken voor een nadruk op eigen verantwoordelijkheid en klinkt de roep om repressie luider. Zo kent Nederland een recente geschiedenis van het inperken van bijvoorbeeld de Werkloosheidswet (WW) en kwamen kosten van de zorg steeds meer bij de burger zelf te liggen. De in het Lenteakkoord aangekondigde 
bezuinigingen doen hier nog een schep bovenop: op de WW wordt verder bezuinigd, het eigen risico in de zorg gaat omhoog en er wordt een eigen bijdrage ingesteld per dag dat men in het ziekenhuis ligt.

In het huidige politieke (en in mindere mate maatschappelijke) debat maakt men zich hoofdzakelijk druk om koopkrachtplaatjes. Opvallend stil is het rondom de vraag wat de sociale kosten zullen zijn van deze verdere inperking van 'de linkerhand van de staat'. Ook is er maar weinig aandacht voor de vraag hoeveel geld het de staat op langere termijn gaat kosten, als deze sociale kosten worden genegeerd.

Wat zijn die sociale kosten? Het gaat dan bijvoorbeeld om mensen die, door het koopkrachtverlies, geen contributie meer kunnen betalen voor vrijetijdsverenigingen, maar ook om vrijetijdsverenigingen die door een gebrek aan middelen de handdoek in de ring moeten gooien. Het gevolg is dat minder mensen deelnemen aan allerlei maatschappelijke activiteiten. Het gaat hier ook om allerlei initiatieven binnen - vooral behoeftige - buurten en gemeenschappen, die afhankelijk zijn van subsidiëring en niet meer levensvatbaar blijken. Denk hierbij aan jeugd- en wijkcentra. Belangrijke gemeenschappelijke aanspraak- en aanspreekpunten verdwijnen, vooral in wijken waarin veel mensen wonen die het sociaal-economisch moeilijk hebben. Sociologen vinden steeds vaker bewijs voor het zogeheten 'crowding-in' effect: in welvaartstaten waar de overheid meer spendeert aan sociale zekerheid, nemen burgers vaker passief en actief deel aan vrijwillige organisaties (Van Oorschot \& Arts, 2005 en Gesthuizen, Van der Meer \& Scheepers, 2008) en bezoeken zij ook vaker familie en vrienden (Van Oorschot \& Arts, 2005). En andere studies wijzen weer uit dat meer van dit 'sociaal kapitaal' in gemeenschappen, samenhangt met minder criminaliteit en meer gezondheid (Putnam, 2000; Uslaner \& Dekker, 2001). Voor burgers zelf zijn deze maatschappelijke activiteiten ook van groot belang. De contacten die men daar opdoet, dienen niet alleen als een prettige besteding van de tijd. Ze genereren ook informatie en kansen. Het zijn deze gemeenschappelijke ijkpunten waar mensen vertier vinden, hun zorgen kunnen delen en gerichte informatie kunnen krijgen waarmee persoonlijke problemen kunnen worden aangepakt: de linkerhand die burgers op weg helpt. Veel sociologisch onderzoek laat zien dat burgers die een hoogwaardig sociaal netwerk hebben - zowel in grootte als wat betreft de maatschappelijke positie van de netwerkleden - minder vaak werkloos zijn en betere banen hebben dan burgers die deze netwerken moeten ontberen (Lin, 1999).

Wat te denken van de mensen die, door de toenemende kosten in de zorg, besluiten zich niet meer te laten behandelen. Milde geestelijke problematiek kan, bij het ontbreken van begeleiding, makkelijk omslaan in ernstiger problematiek. En ook mensen met ernstige psychische klachten mijden de zorg meer en meer, zoals blijkt uit het artikel 'patiënt 
GGZ mijdt zorg' (www.nos.nl, 28-02-2012). In ditzelfde bericht valt een waarschuwing te lezen van staatsecretaris Teeven voor de overlast die dit teweeg kan brengen, waarmee minister Schippers vooralsnog niets wenst te doen. Ook mensen met lichamelijke klachten besluiten mogelijk vaker om een kwaal onbehandeld te laten. Door bezuiniging boet, kortom, zowel de behandelende als preventieve werking van de gezondheidszorg aan kracht in.

Bezuinigingen op de linkerhand van de staat gaan daarmee samen met onbedoelde, onwenselijke gevolgen als meer criminaliteit, meer ongezondheid en minder kansen om vooruit te komen in het leven. En wat mogelijk begint als een persoonlijk of lokaal probleem, kan, als er maar lang genoeg niets aan wordt gedaan, uitgroeien tot een maatschappelijk probleem, met hoge sociale kosten. En deze sociale kosten overstijgen allicht de financiële baten behaald uit bezuinigingen.

De rekenmodellen van het Centraal Planbureau (CPB) bevatten geen parameters voor deze sociale kosten. Ook worden er geen schattingen gemaakt van de extra investeringen die nodig zijn om die sociale kosten op een wat langere termijn te ondervangen. En niet onwaarschijnlijk zijn er meer investeringen nodig, naarmate deze maatschappelijke problematiek langer wordt genegeerd.

In 2006 bracht de Wetenschappelijke Raad voor het Regeringsbeleid (WRR) een interessant rapport uit: De verzorgingsstaat herwogen: over verzorgen, verzekeren, verheffen en verbinden. Deze studie verscheen in een tijd van voorspoed: na een economische dip die eindigde in 2005, maar vóór de kredietcrisis en de huidige uitwas daarvan. Vreemd was het dan ook niet dat er ruim aandacht was voor verheffen en verbinden, als de modernere functies van de verzorgingsstaat, tegenover de meer traditionele functies van verzorgen en verzekeren. Een adequaat financieel vangnet moest dan wel worden geboden (verzorgen) en burgers moesten worden verzekerd tegen loonderving en de kosten van medische zorg (verzekeren), maar de moderne verzorgingsstaat zou haar aandacht vooral meer rechtstreeks moeten richten op het bieden van mogelijkheden aan mensen om op een zinvolle en verantwoorde wijze invulling te geven aan hun leven, en om hun talenten te kunnen ontplooien (verheffen) en het versterken van sociale bindingen tussen burgers (verbinden).

Verzorgen en verzekeren zijn noodzakelijke voorwaarden voor wat in Westerse samenlevingen wordt gezien als een menswaardig bestaan. En een verzorgingsstaat die haar burgers beter verzorgt en verzekert, zal ook met verheffen en verbinden hogere ogen gooien, al is het maar omdat door verzorgen en verzekeren sociale scheidslijnen minder scherp worden. Zo is recent aangetoond dat in landen waar de overheid veel spendeert aan sociale zekerheid, verschillen kleiner zijn tussen laaggeschoolden en hooggeschoolden in economische kwetsbaarheid (een 
laag inkomen gecombineerd met daar ook moeilijk mee rond kunnen komen; Gesthuizen \& Scheepers, 2010) en in gezondheid (Gesthuizen, Huijts \& Kraaykamp, 2011). Van Ingen en Van der Meer (2011) laten overtuigend zien dat de verschillen in verenigingsdeelname tussen armen en rijken, en tussen laag- en hoogopgeleiden, kleiner zijn in landen waar de overheid veel investeert in sociale zekerheid. De bezuinigingen in de gezondheidszorg en de WW zullen dan ook zeer waarschijnlijk het meest neerslaan bij kwetsbare groepen als de laagopgeleiden en de armen. Dit zal vooral voor hen tot meer moeite leiden om zich te verheffen en om zich te verbinden met andere sociale groepen.

Het mogelijk maken van ontplooiing van talent en het in contact brengen van mensen van verschillende pluimage, zijn, in mijn optiek, onderdeel van de moderne linkerhand van de staat. Het zijn deze functies van de verzorgingsstaat die ervoor zorgen dat burgers kansen krijgen om succesvol en gezond te zijn - en te blijven. Hiervan zullen lokale gemeenschappen profiteren, evenals de samenleving als geheel. Helaas zijn juist verheffen en verbinden voor een belangrijk deel van het politieke strijdtoneel verdwenen.

\section{Maurice Gesthuizen}

\section{Literatuur}

Gesthuizen, M. \& Scheepers, P. (2010). Economic vulnerability among low-educated Europeans: Resource, composition, labour market and welfare state influences', Acta Sociologica, 53, 247-267.

Gesthuizen, M., Huijts, T. \& Kraaykamp, G. (2011). De gezondheidskloof tussen lager en hoger opgeleiden. Verschillen tussen landen verklaard door overheidsuitgaven in de gezondheidszorg en arbeidsmarktomstandigheden, Mens \& Maatschappij, 86, 157-181. (Tevens verschenen in 2012 in Sociology of Health \& Illness).

Gesthuizen, M., van der Meer, T. \& Scheepers, P. (2008). Education and dimensions of social capital: Do educational effects differ due to educational expansion and social security expenditure? European Sociological Review, 24, 617-632.

Ingen, E. van \& Van der Meer, T. (2011). Welfare state expenditure and inequalities in voluntary association participation. Journal of European Social Policy, 21, 302-322.

Lin, N. (1999). Social Networks and Status Attainment. Annual Review of Sociology, 25, 467-487.

Oorschot, W. van \& Arts, W. (2005). The social capital of European welfare states: The crowding out hypothesis revisited. Journal of European Social Policy, 15, 5-26. 
Putnam, R.D. (2000). Bowling alone: The collapse and revival of American community. New York: Simon and Schuster.

Uslaner, E. \& Dekker, P. (2001). The 'social' in social capital. In Dekker, P. \& Uslaner, E. (red.) Social capital and participation in everyday life (pp. 176187). London/New York: Routledge.

Wacquant, L. (2008). Urban outcasts: A comparative sociology of advanced marginality. Cambridge: Polity Press.

WRR (2006). De verzorgingsstaat herwogen: over verzorgen, verzekeren, verheffen en verbinden. Amsterdam: Amsterdam University Press. 